\title{
CONTENTS
}

I. THE PRESENT RELATIONS OF SCIENCE AND RELIGION: Professor C. D. BROAD . . . . . . . . . . I3I

II. ON THINGS IN THEMSElves: Professor H. F. Hallett . $\quad$ I55

III. THE AESTHETIC DOCTRINES OF SAMUEL ALEXANDER: Lord Listowel, Ph.D. . . . . . . . . . . 180

IV. PHILOSOPHY AS ACTION: Professor J. W. Scott . . . . 192

V. DISCUSSION: PROFESSOR WHITEHEAD'S Modes of Thought Professor W. G. DE BURGH . . . . . . . . . 205

VI. PHILOSOPHICAL SURVEY:

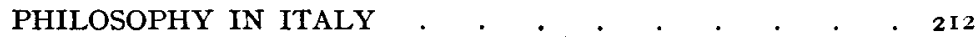

VII. NEW BOOKS • . . . . . . . . . . . 215

VIII. CORRESPONDENCE . . . . . . . . . . . . 254

IX. INSTITUTE NOTES . . . . . . . . . . 255

\section{THE BRITISH INSTITUTE OF PHILOSOPHY}

Appeal for New Members and Donations

THE Council appeals to members to do all in their power to introduce new members in order to extend the benefits of the Institute and to increase its revenue.

The Institute has no endowments, and its work, which includes lecture courses and meetings for discussion in the various Centres, as well as the conduct of the Journal, cannot be carried on from revenue derived solely from subscriptions of $£^{1}$ Is. per annum. The Council, therefore, appeals for donations, small or large, from sympathizers with the Institute's aims. 
PRINTED IN GRHAT BRITAIN BY UNWIN BROTHERS LIMITED

LONDON ANDWOKING 